\title{
Durrington Walls and the Stonehenge Hidden Landscape Project 2010-2016
}

\author{
Vincent Gaffney ${ }^{1}$, Wolfgang Neubauer ${ }^{2,3}$, Paul Garwood ${ }^{4}$, Christopher Gaffney ${ }^{1}$, Klaus Löcker ${ }^{2,5}$,

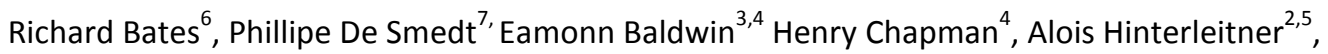 \\ Mario Wallner, ${ }^{2}$, Erich $\mathrm{Nau}^{2}$, Roland Filzwieser ${ }^{2}$ Jakob Kainz ${ }^{2,3}$, Tanja Trausmuth ${ }^{2}$, Petra \\ Schneidhofer ${ }^{2,3}$, Georg Zotti ${ }^{2}$, Agatha Lugmayer ${ }^{2}$, Immo Trinks ${ }^{2}$ \& Alex Corkum ${ }^{1}$
}

1 University of Bradford, 2 Ludwig Boltzmann Institute for Archaeological Prospection and Virtual Archaeology, Hohe Warte 38, A1190 Wien, Austria 3 University of Vienna, Vienna Institute for Archaeological Science, Franz-Klein-Gasse 11, A-1190 Wien 4 University of Birmingham, 5 Central Institute for Meteorology and Geodynamics, Hohe Warte 38, A-1190 Wien 6 University of St. Andrews, 7 Ghent University, Research Group Soil Spatial Inventory Techniques, Department of Soil Management, Faculty of Bioscience Engineering, Coupure 653, B-9000 Ghent, Belgium

Abstract:

Since 2010 the Stonehenge Hidden Landscapes Project (SHLP) has undertaken extensive archaeological prospection across much of the landscape surrounding Stonehenge. These remote sensing and geophysical surveys have revealed a significant number of new sites and landscape features whilst providing new information on many previously known monuments. The project goal to integrate multimethod mapping over large areas of the landscape has also provided opportunities to re-interpret the landscape context of individual monuments and, in the case of the major henge at Durrington Walls, to generate novel insights into the structure and sequence of a monument which has attracted considerable research attention over many decades. This paper outlines the recent work of the SHLP and the results of survey at Durrington Walls that shed new light on this enigmatic monument including a site 'hidden' within the monument.

Keywords: archaeological prospection, landscape archaeology, remote sensing, geophysics, Stonehenge, Durrington Walls 
In 2012 The Stonehenge Hidden Landscapes Project (SHLP) published a short report in Archaeological Prospection (Gaffney et al. 2012) describing the project goals, the nature of fieldwork to be undertaken and the extent of the survey area. The primary aim of the project was to produce a new understanding of the Stonehenge landscape that transcends the interpretative limitations of traditional monument- and site-focused approaches to field investigation characteristic of previous studies within the world heritage site (Bowden et al. 2016; Cleal et al. 1994; David \& Payne 1997; Field et al. 2014). In contrast, the SHLP has applied a range of geophysics and remote sensing technologies at a true 'landscape scale' to create a seamless map of subsurface and surface archaeological features and structures, encompassing both known monuments and new discoveries as elements within richly detailed and far more spatiallyextensive survey datasets.

The prospection methodology proposed by the project team in 2009 was initially planned to cover c. 8 sq $\mathrm{km}$. This was undoubtedly an ambitious undertaking that was made possible only through advances in acquisition, processing, visualization of prospection data. Equally significant was the provision of a technical resource provided through a pan-European research consortium centred on the Ludwig Boltzmann Institute for Archaeological Prospection and Virtual Archaeology (LBI ArchPro) in Vienna (Trinks et al. 2015; 2010). This included a British consortium comprising the Universities of Birmingham, Bradford and St Andrews, which were then joined by the University of Ghent in 2012.

The initial survey area focused on the visual territory of Stonehenge, sometimes referred to as the 'Stonehenge envelope', as defined by Cleal and Allen (Cleal et al. 1995, 34-40). In the earlier interim report (Gaffney et al. 2012), it was reported that approximately $6.3 \mathrm{sq}$. km of the target area had been surveyed contiguously with magnetometer and targeted surveys using seven primary methods with up to 18 different instruments and configurations. Since 2012, the overall survey area has significantly exceeded the original goal and now comprises c. $26 \mathrm{sq} \mathrm{km}$, representing the sum of multiple sensor surveys over c. $10 \mathrm{sq}$. $\mathrm{km}$ of contiguous mapped area. The detail of this work is provided in Table 1 , and its extent may usefully be compared to the estimated $3.16 \mathrm{sq} . \mathrm{km}$ of all other geophysical surveys in the Stonehenge landscape combined, including the 2005 (Darvill 2005, 14-15), the small-scale Stonehenge Riverside Project (SRP) geophysical surveys (Parker Pearson 2012), and the more recent single-method surveys carried out since the start of the SHLP by Darvill et al. (2013) and by Historic England in advance of the proposed A303 tunnel (Barker et al. 2015).

The sheer scale, resolution and complexity of the data produced by the SHLP are unprecedented in terrestrial prospecting. The results range from discoveries of new prehistoric monuments to finely detailed mapping of extensive multi-period field systems and modern complexes such as RAF 
Stonehenge. Inevitably, there is particular interest in the landscape context of Stonehenge itself in the 3rd millennium BC, our knowledge of which has greatly increased as a result of the project. The wealth of data generated is now being prepared for publication, and there is no space here to report or comment on the new data produced or its research significance in any detail, but it is possible to draw attention to the implications of some aspects of the new geophysical survey evidence for understanding the landscape at the time Stonehenge was built and the wider articulation of late Neolithic activity and monument-building.

\begin{tabular}{|c|c|c|c|c|c|c|c|c|c|c|c|}
\hline \multicolumn{12}{|c|}{ STONEHENGE HIDDEN LANDSCAPES - REMOTE SENSING TECHNIQUES SUMMARY } \\
\hline & & & & 2010 & 2011 & 2012 & 2013 & 2014 & 2015 & 2016 & Total \\
\hline Technique & Option & Feature & Landsacpe & Area (ha) & Area (ha) & Area (ha) & Area (ha) & Area (ha) & Area (ha) & Area (ha) & Area (ha) \\
\hline \multirow[t]{2}{*}{ Earth Resistance } & Twin & $\mathrm{x}$ & - & - & 0.04 & - & - & - & - & - & 0.04 \\
\hline & Square & $\mathrm{x}$ & - & 0.32 & - & - & - & - & - & - & 0.32 \\
\hline \multirow[t]{2}{*}{ Electrical Imaging } & Campus Tigre RM & $\mathrm{x}$ & - & 0.00 & - & - & - & 0.10 & 0.15 & - & 0.26 \\
\hline & FlashRES64 & $\mathrm{x}$ & - & - & 0.34 & - & - & - & - & - & 0.34 \\
\hline \multirow[t]{4}{*}{ Magnetometer } & CV Cart & $\mathrm{x}$ & - & - & 3.83 & - & - & - & - & - & 3.83 \\
\hline & FF Cart & $\mathrm{x}$ & $x$ & 15.10 & - & 5.00 & 15.00 & - & - & - & 35.10 \\
\hline & FF Motorised & $x$ & $x$ & 28.16 & 221.10 & 482.00 & 219.00 & 21.00 & - & 51.70 & 1022.96 \\
\hline & Bartington $\mathrm{HH}$ & $\mathrm{x}$ & - & 4.40 & - & - & 1.20 & - & - & - & 5.60 \\
\hline \multirow[t]{3}{*}{ GPR } & Mala Motorised & $\mathrm{x}$ & $x$ & 16.80 & 31.90 & - & 22.00 & 40.00 & - & 73.50 & 184.20 \\
\hline & S\&S Motorised & $\mathrm{x}$ & $x$ & 13.40 & - & - & 35.00 & - & 9.00 & 12.00 & 69.40 \\
\hline & Single & $\mathrm{x}$ & - & 2.40 & 1.00 & 1.00 & 1.50 & 0.82 & 1.35 & 0.99 & 9.06 \\
\hline \multirow[t]{4}{*}{ EM } & EM31 & $\mathrm{x}$ & $x$ & 0.54 & - & - & - & - & - & - & 0.54 \\
\hline & EM38 & $\mathrm{x}$ & $\mathrm{x}$ & - & - & - & - & - & 0.16 & - & 0.16 \\
\hline & Dualem motorised & & $x$ & - & - & 21.00 & 22.00 & 153.00 & 100.00 & - & 296.00 \\
\hline & CMD Mini Explorer & $\mathrm{x}$ & - & - & 1.60 & - & - & 25.00 & 0.16 & - & 26.76 \\
\hline \multirow[t]{5}{*}{ Laserscan } & Leica & $\mathrm{x}$ & - & 2.30 & 3.30 & 0.50 & 1.00 & 1.75 & 2.36 & 2.61 & 13.82 \\
\hline & Riegl & - & $x$ & - & 287.00 & 217.00 & 446.20 & - & - & - & 950.20 \\
\hline & & & & 83.4 & 550.1 & 726.5 & 762.9 & 241.7 & 113.2 & 140.8 & $2,618.6$ \\
\hline & & & & 2010 & 2011 & 2012 & 2013 & 2014 & 2015 & 2016 & Total \\
\hline & & & & Area (ha) & Area (ha) & Area (ha) & Area (ha) & Area (ha) & Area (ha) & Area (ha) & Area (ha) \\
\hline
\end{tabular}

\section{Geophysic}

Table 1. Techniques used during the Stonehenge Hidden Landscapes Project (SHLP) 2010-2016.

It is striking, for example, that there are many more henge and 'hengiform' monuments scattered across the entirety of the Stonehenge landscape than hitherto imagined. A sample of these, of diverse architectural forms and sizes, is shown in Fig. 1. These include the ovate penannular henge with a slightly angular ditch circuit at Amesbury 41, later modified by the addition of a round mound (Fig. 1, A), and two small penannular 'mini-henges' at Amesbury 38a (the first, innermost monument phase; Fig. 1, B), and 
Amesbury 95 (Fig. 1, C). Other small penannular ditches may also be late Neolithic in date, if not small round barrows, such as a new discovery near the Old King Barrows (Fig. 1, D). Two more henge-like sites, both assimilated by later round mounds (Amesbury 50 and 9), include ovate settings of large closeset and regularly spaced pits probably either for timber or stone settings. Amesbury 50 (Fig. 1, E) consists of a slightly angular oval array of pits within two opposed arcs of large quarry pits, probably for external banks, forming an oval arena with entrances to the north-east and south-west. Amesbury 9 (Fig. 1, F) has a similar but more rounded oval arrangement of pits enclosed by an irregular segmented 'hengiform' ditch (cf. Linford et al. 2012). Several more irregularly-shaped segmented and penannular ditches, and pit circles, of various shapes and sizes, are almost certainly variants of late Neolithic hengiform monuments. These include sites near the east end of the Great Cursus (Fig. 1, G, H), Amesbury 115 (Fig. 1, I), two newly-discovered sites in the Palisade Field (Fig. 1, J, K), another to the east of King barrow Ridge (Fig 1, L), Amesbury 139 (Fig. 1, M), and new monuments near Durrington Walls (Fig. 1, N, O). Other, previously-known ring ditch sites have also been shown to have segmented rather than continuous ditches, such as Winterbourne Stoke 24 (Fig. 1, P), and the ring ditch within the Lesser Cursus (Fig. 1, Q), that seem most closely related to early Beaker funerary monuments of the late $3^{\text {rd }}$ millennium BC (cf. Darvill 2005, 51-2). Finally, many Early Bronze Age round barrow and ring ditch sites surveyed within the study area include features that may indicate pre- or post-mound construction phases, including apparent pit circles (such as Amesbury 135; Fig. 1, R).
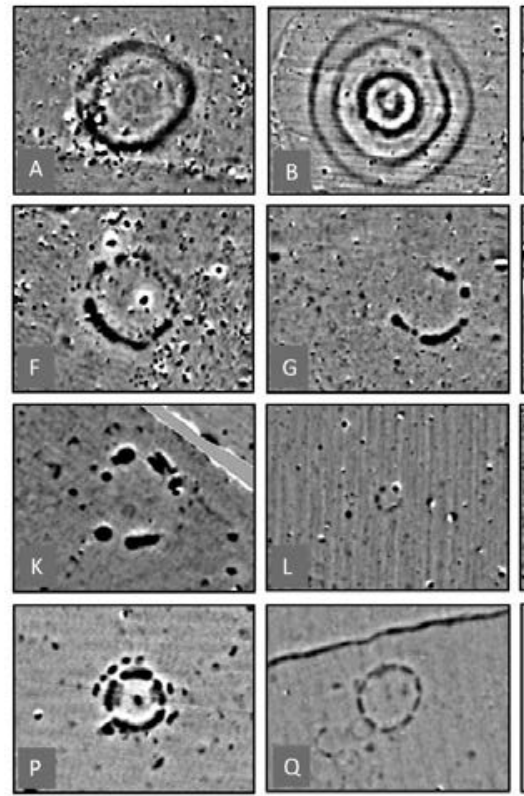
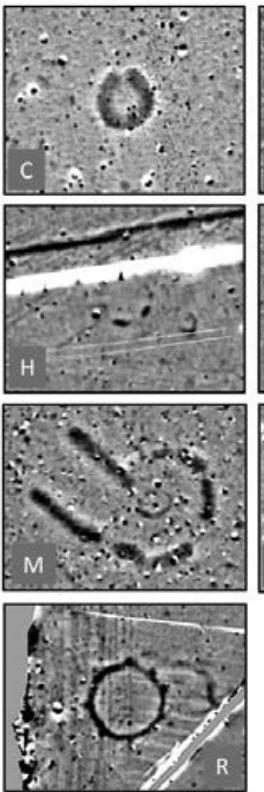
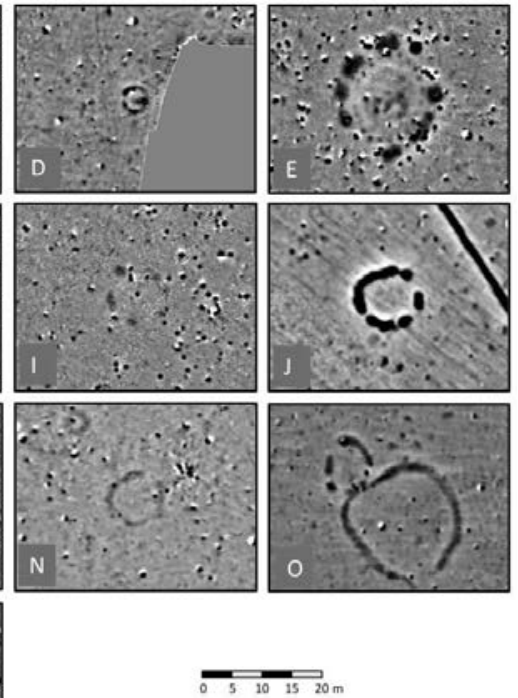

Figure 1: Magnetograms of 18 monuments of probable 3rd millennium BC date mapped within the SHLP study area (LBI ArchPro, Mario Wallner; modified by Paul Garwood).

This evidence suggests a landscape in the early to mid- $3^{\text {rd }}$ millennium $\mathrm{BC}$ with a quite dense if scattered distribution of late Neolithic ceremonial monuments (Fig. 2), many within sight of Stonehenge itself. Although the precise dating of these sites is unknown, and the chronology and changing character of 
both monumentality and ceremonial practices are uncertain, it is apparent that construction of the Stonehenge stage 2 sarsen and bluestone monument in the $26^{\text {th }}$ century BC (Darvill et al. 2012, 1030-34) took place in a 'busy' social landscape of ritual and symbolic representation. This is quite unlike the conventional image of a relatively deserted ancient 'sacred landscape' dominated by a central monument standing in 'splendid isolation'. Instead, this new evidence points towards a multiplicity of shrines and ceremonial arenas, some ancient and abandoned, others in contemporary use, in some cases with striking timber or stone structures, located amongst a mesh of routes and pathways that Stonehenge was as much entangled with as the other monuments around it.

There is no reason to imagine that this landscape picture changed with Beaker graves and moundbuilding from c. $2400 \mathrm{BC}$. The scattered distribution of these burial monuments amongst earlier ceremonial sites, with many barrows revisited on numerous occasions for new interments and/or as ancestral shrines, required routes - and rights - of access. Indeed, some are arrayed in lines, probably situated on pathways that cross-cut the Stonehenge landscape (Garwood 2012). Only the physical constraints and more overt spatial separation of landscape zones brought about by the construction of the Avenue approach, probably in the $24^{\text {th }}$ century BC (Allen et al. 2016, 1005; cf. Darvill et al. 2012, 1035), appears to have pushed away other practices. 'Alternative' or seemingly contingent ritual activities such as elite funerals potentially risked distracting attention from Stonehenge as the central ceremonial and symbolic focus of a more exclusive 'sacred landscape'. Even so, this process does not appear to have been realised in formal zonation of practices and monuments until the development of early Bronze Age linear barrow groups in the 19th and 18th centuries BC (Garwood 2007, 44-5; Woodward \& Woodward 1997).

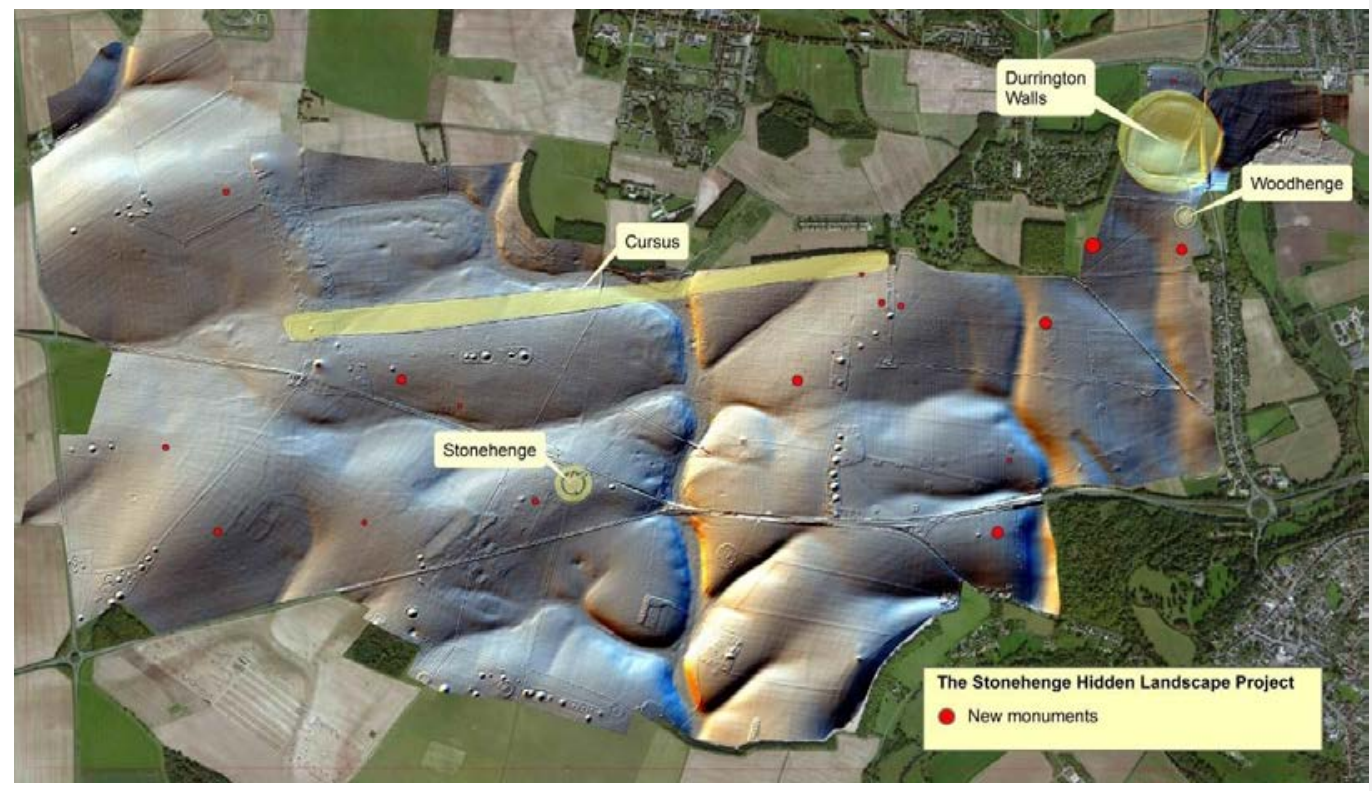

Figure 2: Location of potential Late Neolithic monuments mapped within the SHLP study area overlain on a shaded terrain model (LBI ArchPro, Wolfgang Neubauer) 
In this interpretative context, the significance of the Durrington Walls 'super-henge', located c. $3 \mathrm{~km}$ to the north-east of Stonehenge (Fig. 2, 3), cannot be under-estimated. It has gained special prominence in the literature in recent years not only because of the outstanding discoveries made at the site by the 'Stonehenge Riverside Project' (SRP), notably the pre-henge settlement, but also because the site has a pivotal role in the interpretative model that underpinned the development of the SRP and its overall methodology (Parker Pearson \& Ramilisonina 1998; Parker Pearson et al. 2004). This framework of enquiry and the fieldwork results generated by the SRP have since infused interpretative discussions of the Stonehenge prehistoric landscape. In brief, what is suggested is that Stonehenge and Durrington Walls were counterparts in a single religious and ceremonial scheme, linked physically by meandering routes marked by their respective avenues and by the river Avon itself between the riverside avenue terminals. It is suggested that Stonehenge represents a cosmological focus, bound up with ideas of celestial forces, ancestor spirits, death and renewal, while Durrington Walls was a place for communal gatherings and ritual celebration of the living community. A key theme pervading this model, drawing on ethnographic analogy, is the argument that wooden architecture (such as the timber circles found within Durrington Walls) was metaphorically bound up with ideas of life, growth and vitality, whereas stone architecture (such as Stonehenge) embodied ideas of past worlds, timelessness, cosmos and death, with a logical semantic trajectory leading from life to death, wood to stone.

If this overarching explanatory framework is correct, both Stonehenge and Durrington Walls should have been in existence contemporaneously, stone architecture should not be present at Durrington Walls, and the development of Durrington Walls should be such that monumentalisation does not precede but rather follows the 'domestic life' of the settlement. In this light, the results of the SHLP geophysical and topographical surveys undertaken at Durrington Walls raise a number of questions about this assumed sequence and character of the site, and invite reconsideration of our current understanding of the wider late Neolithic cultural landscape.

The basic outline of site chronology and architecture, based originally on the excavations led by Wainwright in the 1960s (Wainwright \& Longworth 1971), has been revised recently following the work of the Stonehenge Riverside Project (French et al. 2012; Parker Pearson 2007, 2012; Parker Pearson et al. 2007; Thomas 2007). The roughly circular henge enclosure consists of an internal ditch up to $5.5 \mathrm{~m}$ deep and $18 \mathrm{~m}$ wide, and an external chalk rubble bank surviving up to $1.5 \mathrm{~m}$ high and up to c. $32 \mathrm{~m}$ wide, with an overall diameter of c. $480 \mathrm{~m}$. It is generally assumed that the enclosure has two opposed entrances, to the south-east and north-west. The henge entirely surrounds a dry valley connecting to the river Avon, which lies just $170 \mathrm{~m}$ from the south-east entrance, the bank running around the highest points overlooking the valley on the north, west and south sides. It encloses a number of other structures, including two timber circles excavated by Wainwright on the east side of the enclosure (the South and North Circles), interpreted at the time as huge roofed buildings (Wainwright \& Longworth 1971, 204-34), together with a number of small enclosures in a line running north-east to south-west across the centre of the henge, recorded in earlier aerial photographic and geophysical surveys of the site (Crawford 1929; David \& Payne 1997; Payne 2003, 2004). An especially prominent topographic feature is the large scarp just within the enclosure bank on the west and north sides which has been interpreted as an unusually large lynchet resulting from later agricultural activity (Wainwright \& Longworth 1971, 1, 7, fig.3).

The SRP investigations have significantly changed our understanding of the monument. It is now clear that a settlement existed prior to henge construction: nine houses revealed beneath the enclosure bank, dated to c.2525-2440 BC (Parker Pearson 2012, 110-11), were part of a larger settlement that may have extended around the fringes of the dry valley. It has been suggested that this comprised several hundred 
houses inhabited by up to 4000 people (Parker Pearson 2012, 109), although this extrapolation of the excavated south-east entrance area data is conjectural and direct evidence for wider occupation is limited. The excavated houses were positioned on either side of an entrance avenue, oriented on midsummer sunset, linking the river Avon with the South Circle. This later formed the approach route into the henge enclosure itself. The settlement was perhaps occupied for no more than 20 years, abandoned and partly destroyed or buried by earthwork construction when the henge enclosure was built in the period 2480-2450 BC (Darvill et al. 2012, 1036). Excavation of two of the small central enclosures showed that these surround buildings, either 'elite' residences or house-like shrines, which were contemporary with the settlement and/or the henge (Thomas 2007). The SRP investigations have focused far less on the henge enclosure, broadly accepting and enhancing Wainwright's observations concerning construction and form, while considerably rethinking the nature of the internal timber architecture, especially the South Circle and nearby structures such as the D-shaped building, previously thought to be a midden (Parker Pearson 2012).

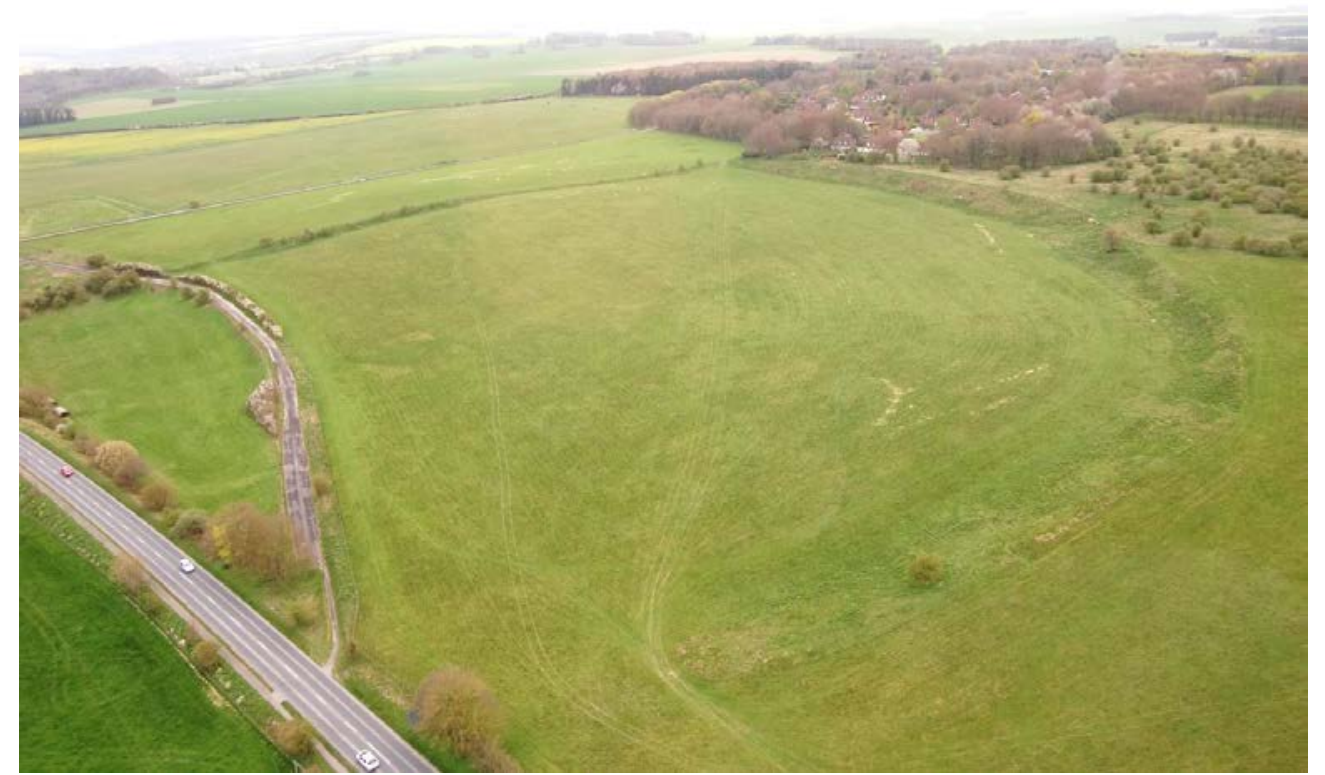

Figure 3: Aerial view of Durrington Walls from the north east illustrating the large scarp on right of image (Photo: Henry Chapman) 


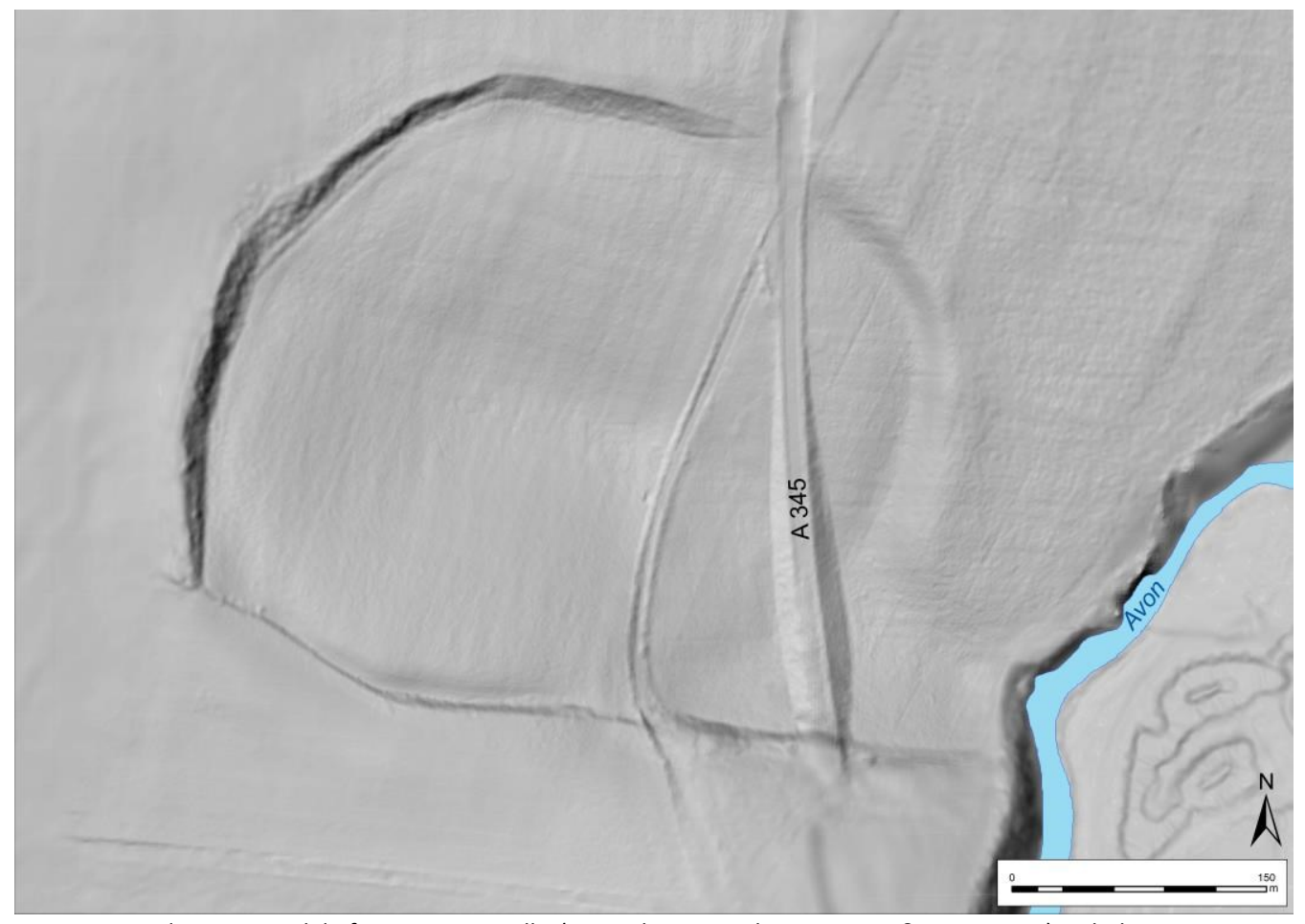

Figure 4: Digital terrain model of Durrington Walls. (LBI ArchPro, Agatha Lugmayer \& Georg Zotti) Including sections

Durrington Walls was among the last areas planned for SHLP survey. The area initially scanned using a Riegl LMS z400 terrestrial laser scanner was extended using a RiegI LMS VZ400 scanner to create a high resolution topographic model of the site and its environs (Fig. 4). A magnetometer survey of the site was undertaken in 2013 using a motorized eight-sensor Foerster fluxgate array with a spatial resolution of 25 $x 10 \mathrm{~cm}$. The higher resolution data provided a relatively clear and uncontroversial image of the monument (Fig. 5) very similar to the 2003/4 survey results (Payne 2003, 2004). The ditch, which is obscured by later deposits within the central and western sector of the henge is clear in the fields east of the old route of the $\mathrm{A} 345$ road. The central enclosures can be clearly seen in the magnetic image along with pit-like structures and later field boundaries. Whilst many other features may be identified, the small enclosure in the north-west part of the henge is notable. Its proximity to the putative northwest entrance may be linked to the presence of a recent trackway in this area.

This magnetometer survey was subsequently followed by a ground penetrating radar survey of the area (Fig. 6) using a motorized Spidar array with six $500 \mathrm{MHz}$ antennae producing a spatial resolution of $25 \mathrm{x}$ $5 \mathrm{~cm}$. The initial GPR survey covered the area between Woodhenge and the southern bank of Durrington Walls, and the interior of the henge west of the old route of the A345 road. The magnetometer and GPR survey were positioned using a Javad Triumph RTK GPS with sub-decimeter accuracy. The results provided a clear image of the positioning and spread of the bank material in relation to the nonconcentric ditch. The internal structure of the bank appears to comprise discontinuous mounded sections, which may reflect a construction process undertaken by several teams, or a sequence of mound-building events, in either case subsequently linked by infilling and further capping. A similar 
process may be evident in the radar and magnetic images of the ditch. In line with project procedure, the monument was then mapped using a number of complementary techniques.

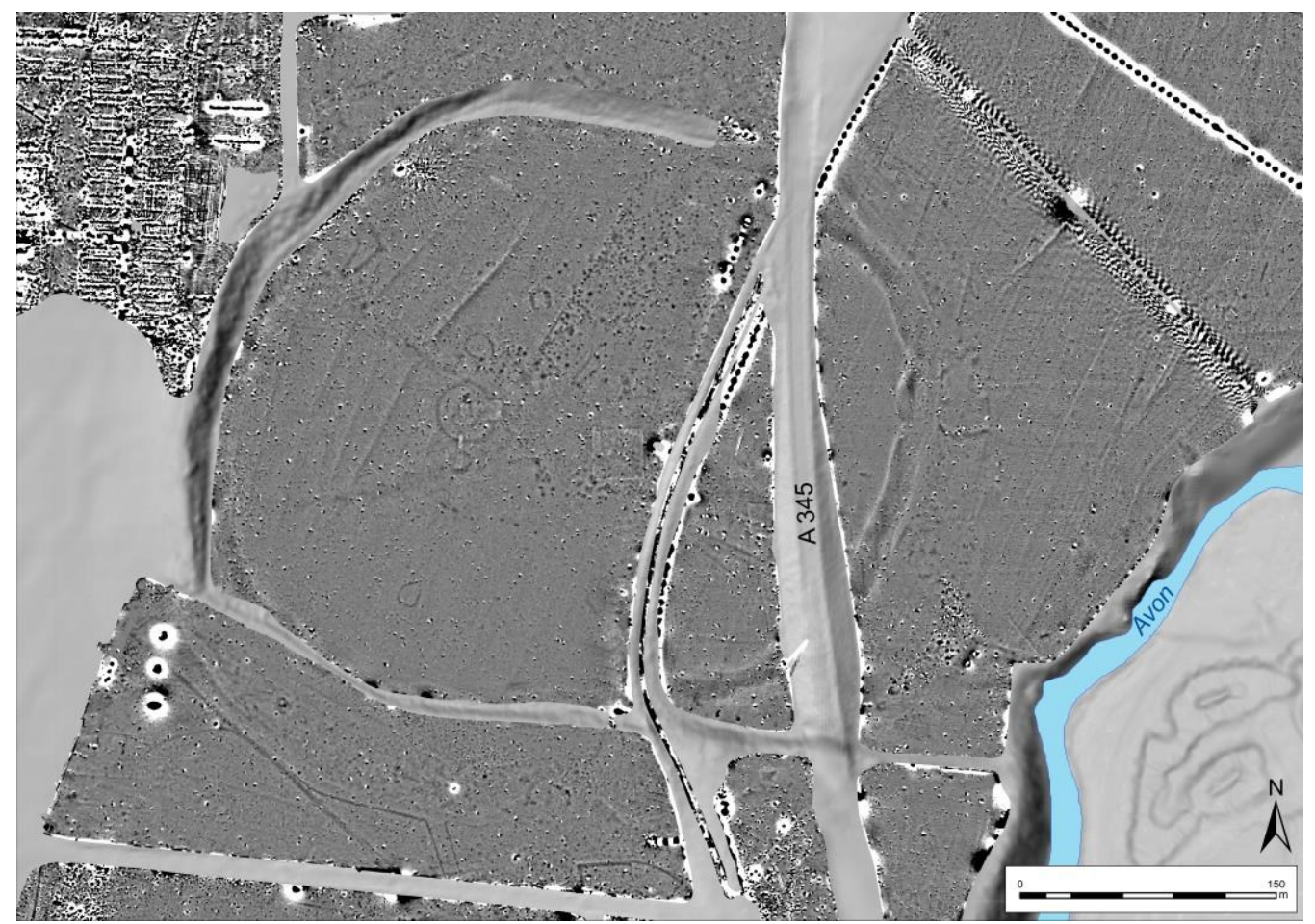

Figure 5: Magnetometer data from Durrington Walls (LBI ArchPro, Mario Wallner \& Klaus Löcker) 


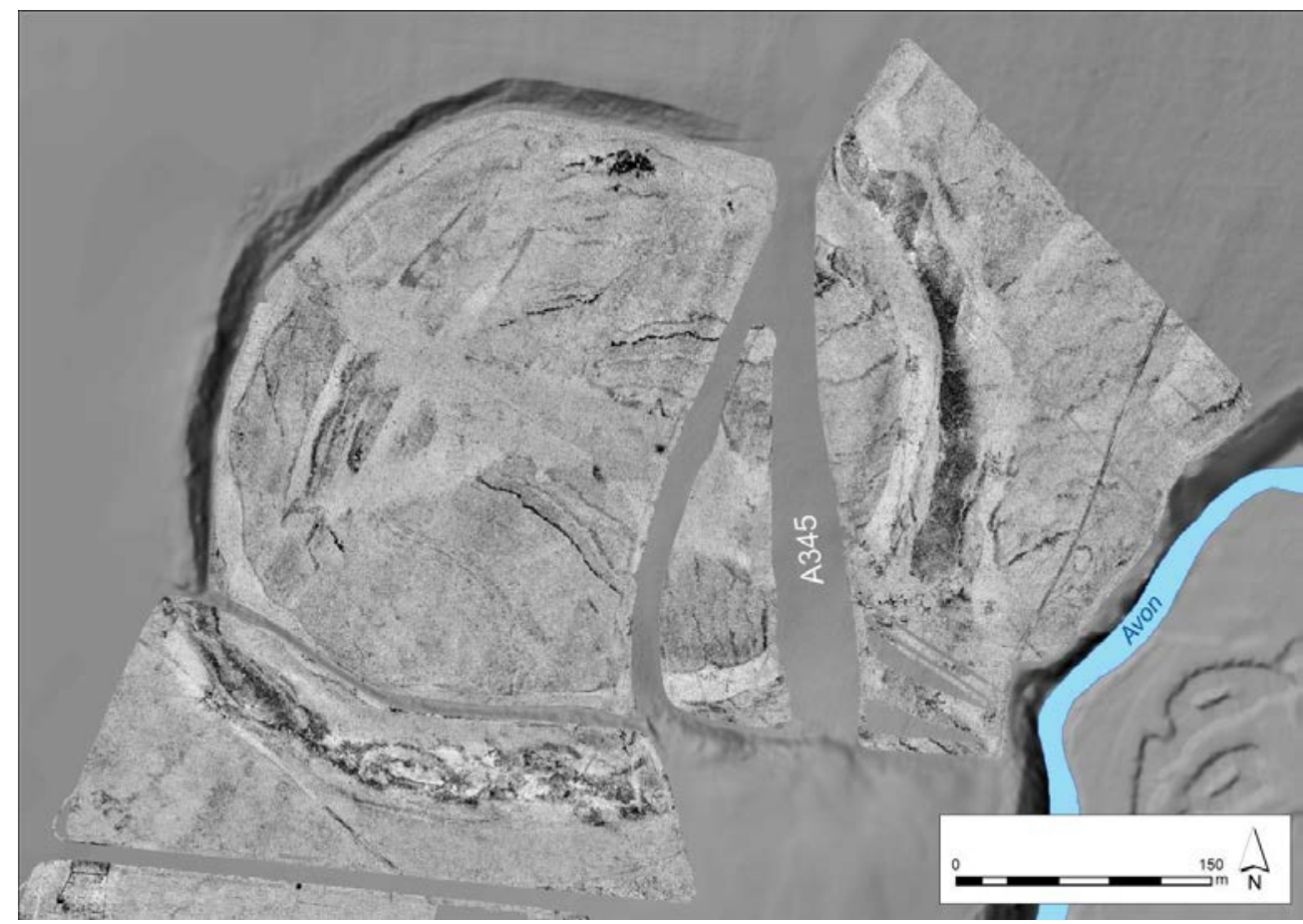

Figure 6: GPR data from Durrington Walls, visualisation of calculated depth slice $40-100 \mathrm{~cm}$ (LBI ArchPro, Mario Wallner \& Klaus Löcker)

Frequency domain electromagnetic induction (FDEM) surveys were carried out over the full area of the enclosure by the University of St Andrews, using a CMD Explorer (GF Instruments) with horizontal coil orientation and a GNSS receiver for real-time positioning (Fig 7). Line spacing was set at a maximum of $4 \mathrm{~m}$ with measurement intervals at $0.3 \mathrm{sec}$ (approximately $0.5 \mathrm{~m}$ along lines). Three coil spacings were simultaneously recorded for both conductivity and in-phase values and, in horizontal coil orientation, the approximate depths of survey for the three coils are 2,4 , and $6 \mathrm{~m}$. 


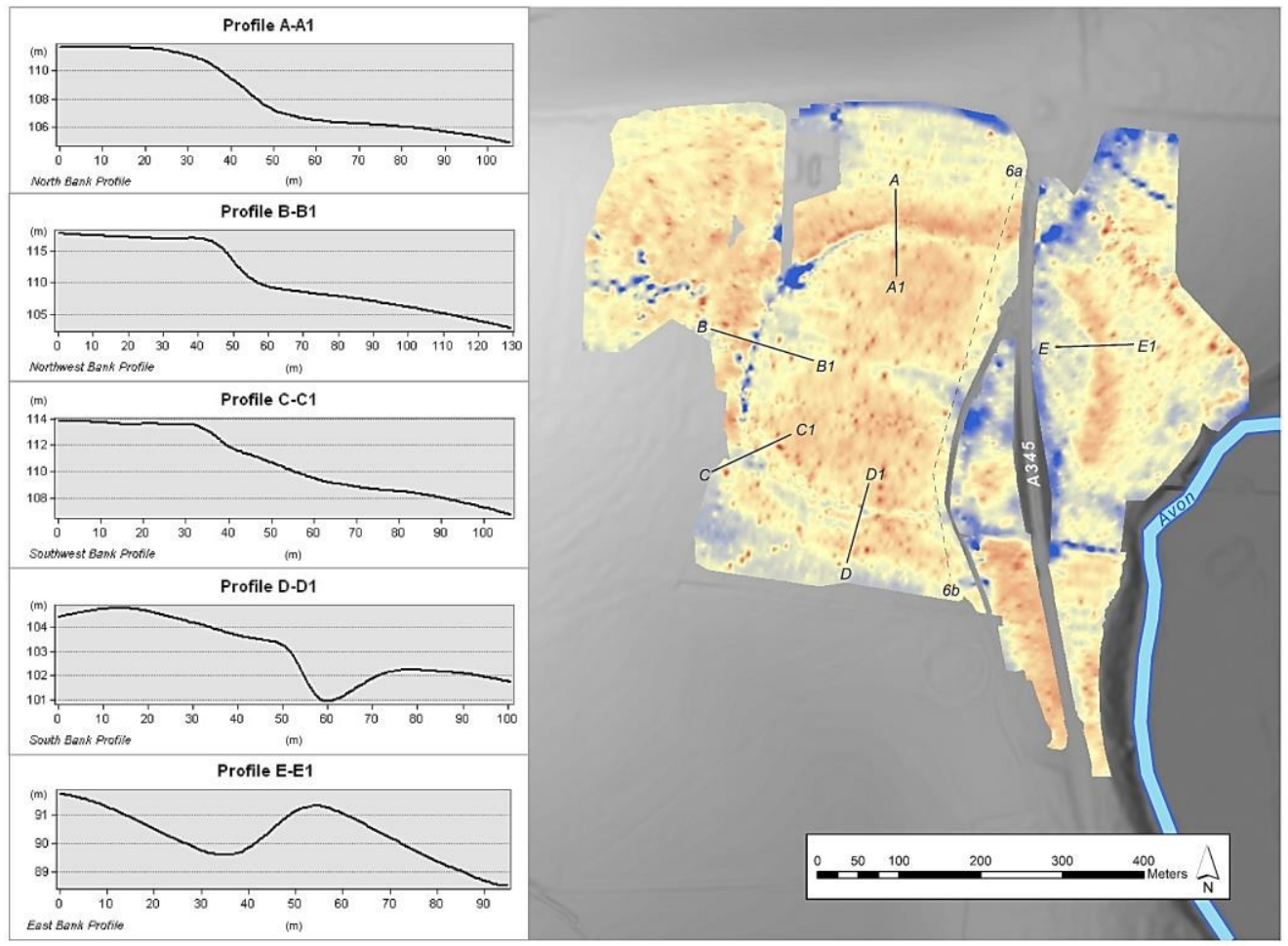

S

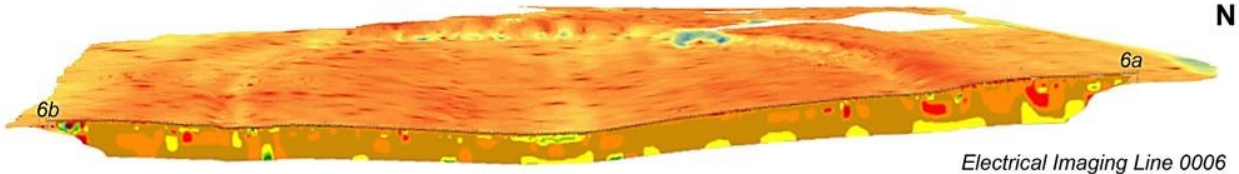

Figure 7:Profiles across bank and scarp with electrical imaging data (Richard Bates (St Andrews), Eamonn Baldwin (University of Birmingham) and Vincent Gaffney (University of Bradford))

Motorized multi-receiver FDEM survey, covering the complete monument at a sampling resolution of 1.2 $\mathrm{m}$ by $0.3 \mathrm{~m}$, was also undertaken in 2015 using a Dualem-21S instrument (following De Smedt et al. 2014), in order to discriminate more shallow subsurface variations. The data collected provided complementary information about the in-phase magnetic susceptibility as well as the apparent electrical conductivity of four soil volumes with approximate depths of investigation varying from 0.5 to c. $3.0 \mathrm{~m}$ beneath the surface. 


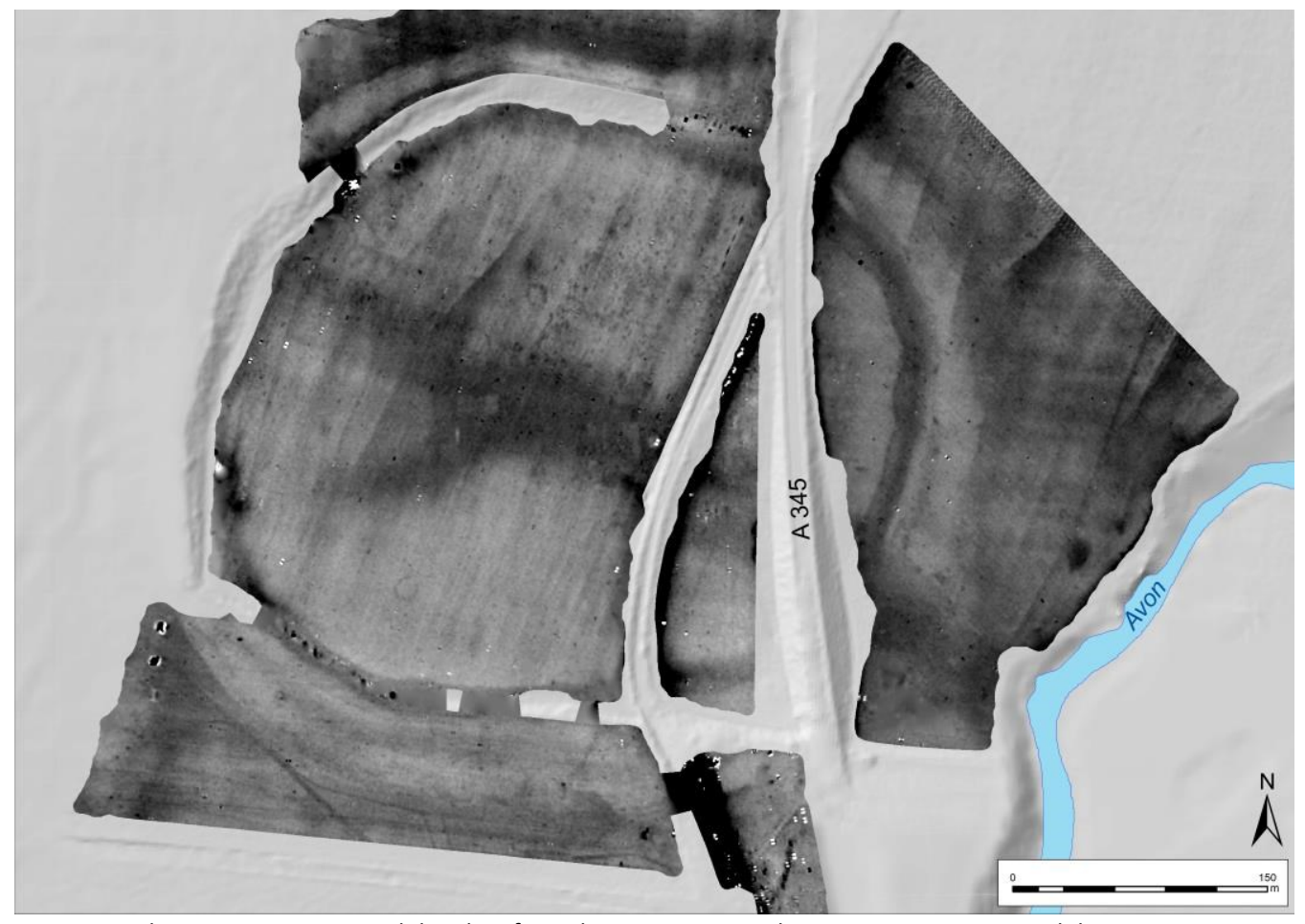

Figure 8: In-phase magnetic susceptibility data from the FDEM survey, showing magnetic susceptibility to a maximum depth of $1.5 \mathrm{~m}$ beneath the surface (Ghent University, Philippe De Smedt)

Electrical Resistivity Tomography (ERT) was used to obtain geo-electric cross-sections (Fig. 7) through the site using a Lund Terrameter SAS4000 plus a Topcon HiperPro. For these surveys an electrode spacing of between 1.0 and $5.0 \mathrm{~m}$ was tested with protocols consisting of a modified Wenner-Dipole array. Data was interpreted for $0.5 \mathrm{~m}$ bins with a maximum penetration of $25.0 \mathrm{~m}$ depth. For integration with the surface FDEM data the cross -section resistivity values were inverted.

The results of the wide area FDEM surveys clearly showed decreased conductivity associated with the area outside the bank. Elsewhere, these data indicate slightly higher conductivity that is correlated with signatures seen with the ERT cross-sections. It was not possible to determine the presence or absence of the assumed north-west entrance in the bank/ditch as there is significant metallic noise at the surface here. Similarly, it is not possible to establish the nature of the apparent breaks on the north and east sides due to the presence of the old and new main roads cutting through the earthworks at these points.

A broad Y-shaped area of higher conductivity was mapped approximately east-west through the centre of the feature coincident with the base of the dry valley (Fig. 8). This was also seen in the magnetic data, GPR depth-slices and the ERT cross-sections. A continuation of this feature extended to the west beyond the site. This may indicate the former presence of ephemeral springs and streams, perhaps of late glacial/early post-glacial date, running from the valley edge down to the Avon. Alternatively, these features have been interpreted as the result of post-Neolithic erosion and colluviation (French et al. 2012, 29-30). 
After the integration of all processed and georeferenced datasets in the main geodatabase the team worked jointly on the initial interpretative mapping using ESRI ArcGIS10.1 and a first version of the ArchaeoAnalyst extension, developed by the LBI ArchPro to support visualization, feature detection and mapping (Fig. 9). This initial interpretation workshop defined the structure of the bank and its relationship to a series of aligned anomalies. Up to 90 large features were identified beneath the remnant bank on the south side of the enclosure to the west of the old A345. Variable in nature and alignment, the GPR responses suggested that the largest of these features are up to $4.5 \mathrm{~m}$ in length and c.1.5 $\mathrm{m}$ in width, and composed of strong reflectors such as individual stones or rubble backfill of dug features. The features were located beneath c. 0.7 to $1.0 \mathrm{~m}$ of bank and topsoil material. Assuming modest to low magnetic contrasts between stone or rubble and surrounding sediments or bedrock, magnetometry and FDEM would not be expected to detect such features.

The provisional interpretation of some of the features as containing stones prompted consultation with Professor Parker Pearson of the SRP who alerted the team to the presence of very large pits underlying the western bank terminal at the south-east entrance, revealed during recent excavations, some of which contained concreted chalk slurry (cf. Parker Pearson 2007). Smaller trenches excavated by the SRP on the edge of the banks near the new features also revealed significant densities of flint in the proximity of the features located through GPR. The potential for the new features to indicate similar fills was considered and prompted further detailed survey to attempt to resolve these issues. 

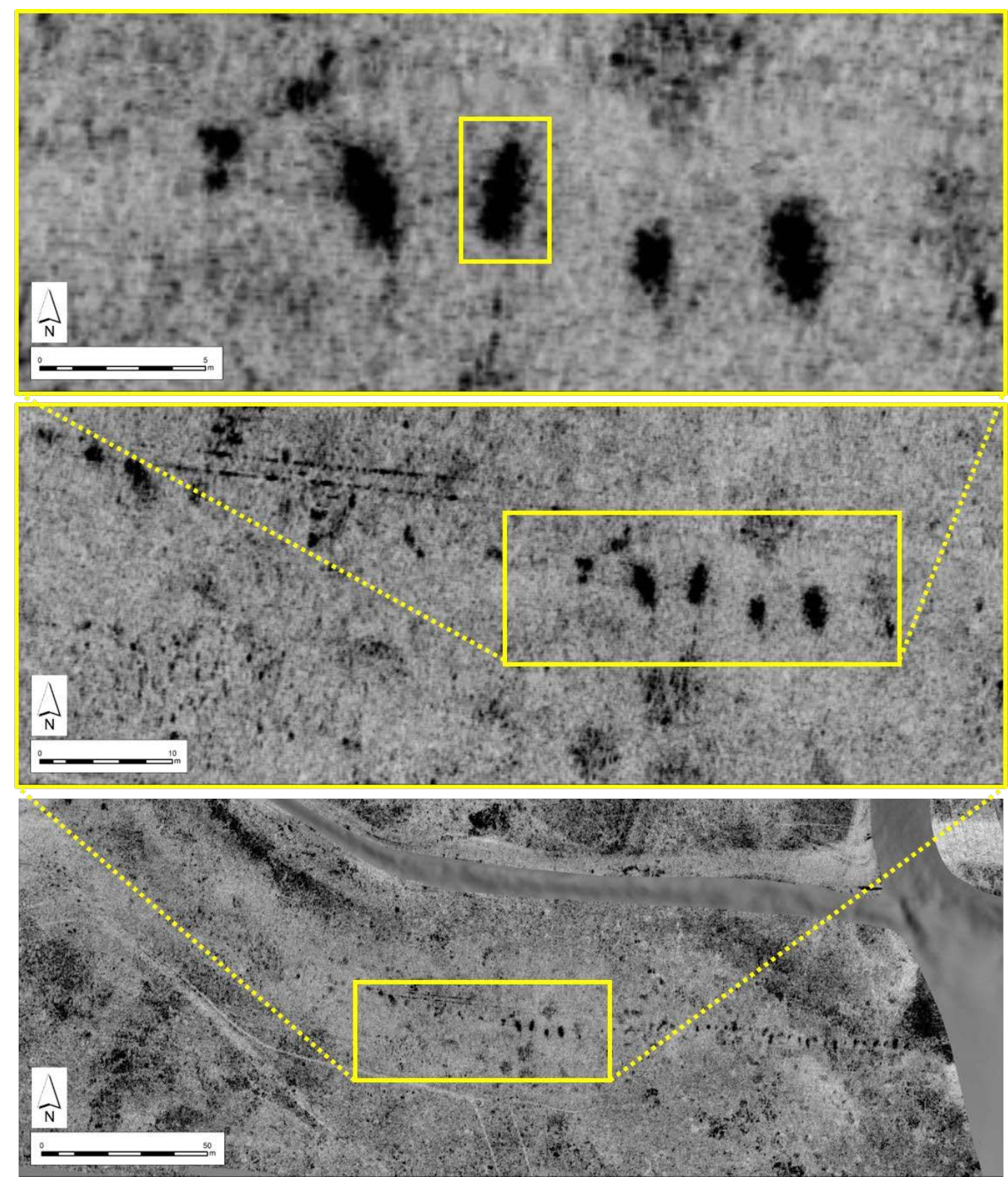

Figure 9: GPR anomalies underlying southern bank. (LBI ArchPro, Mario Wallner, Klaus Löcker, Immo Trinks)

Following these observations, additional GPR surveys were undertaken in 2015 and 2016 using a motorized 16-channel MIRA GPR system with $400 \mathrm{MHz}$ antennae providing a spatial resolution of $8 \times 10$ $\mathrm{cm}$ (Trinks et al. 2010). These re-examined the original survey area and extended this to the north and east to cover the entire monument and its immediate environs. 
This extended survey located similar features in the small area of land between the old and new routes of the $A 345$ (Fig. 12), and on the line of the north-west quadrant of the henge bank (Fig. 13). No features were located, however, in the areas surveyed on the north side of the enclosure, or beneath the wellpreserved eastern bank to the east of the $A 345$.

Additional ERT surveys were carried out over several of these target features in 2015 and later in 2016 (Fig. 10). The results of the 2D and 2.5D surveys identified a series of linear high-resistance anomalies similar in size and shape to those identified in the GPR data. Inevitably, there are discrepancies with regard to depth estimates between the GPR and ERT results, which may be related to the processing or assumptions in the GPR depth estimate.

The ERT survey was conducted with a FlashRes64 (ZZ Geo) utilising 64 electrodes at $0.5 \mathrm{~m}$ electrode separation. Data was collected over two distinct areas in parallel 2 dimensional lines at $0.5 \mathrm{~m}$ separation, yielding a total of $112 \mathrm{D}$ data sets for the first line and 13 for the second. This data was then processed individually with wenner $\alpha$, wenner $\beta$, schlumberger, and double dipole being extracted from the raw data and combined prior to inversion. A GNSS GPS was used to collect electrode location and height values which was used to provide topographic correction of the datasets during inversion. The 2 dimensional data was inverted with robust inversion within the Res2DINV software in both semi and fully $3 D$.

In summary, the data collected suggests that some of these features contained 'hard' fills, perhaps including flint, stone rubble or in situ stones.

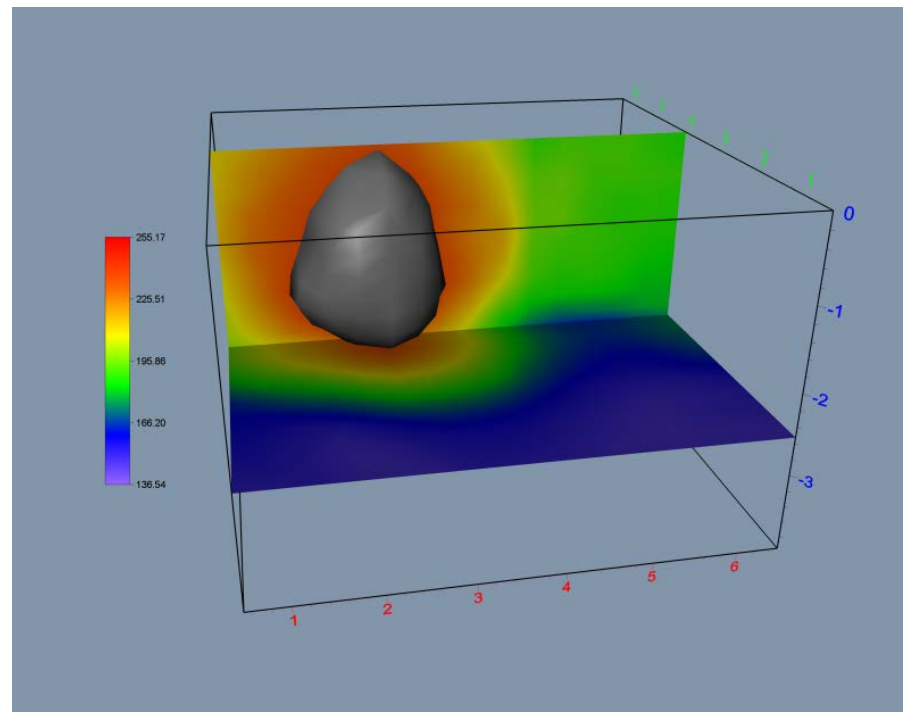

Figure 10:

Fully 3D ERT Volume over one of the high resistivity anomalies collected in 2015. 


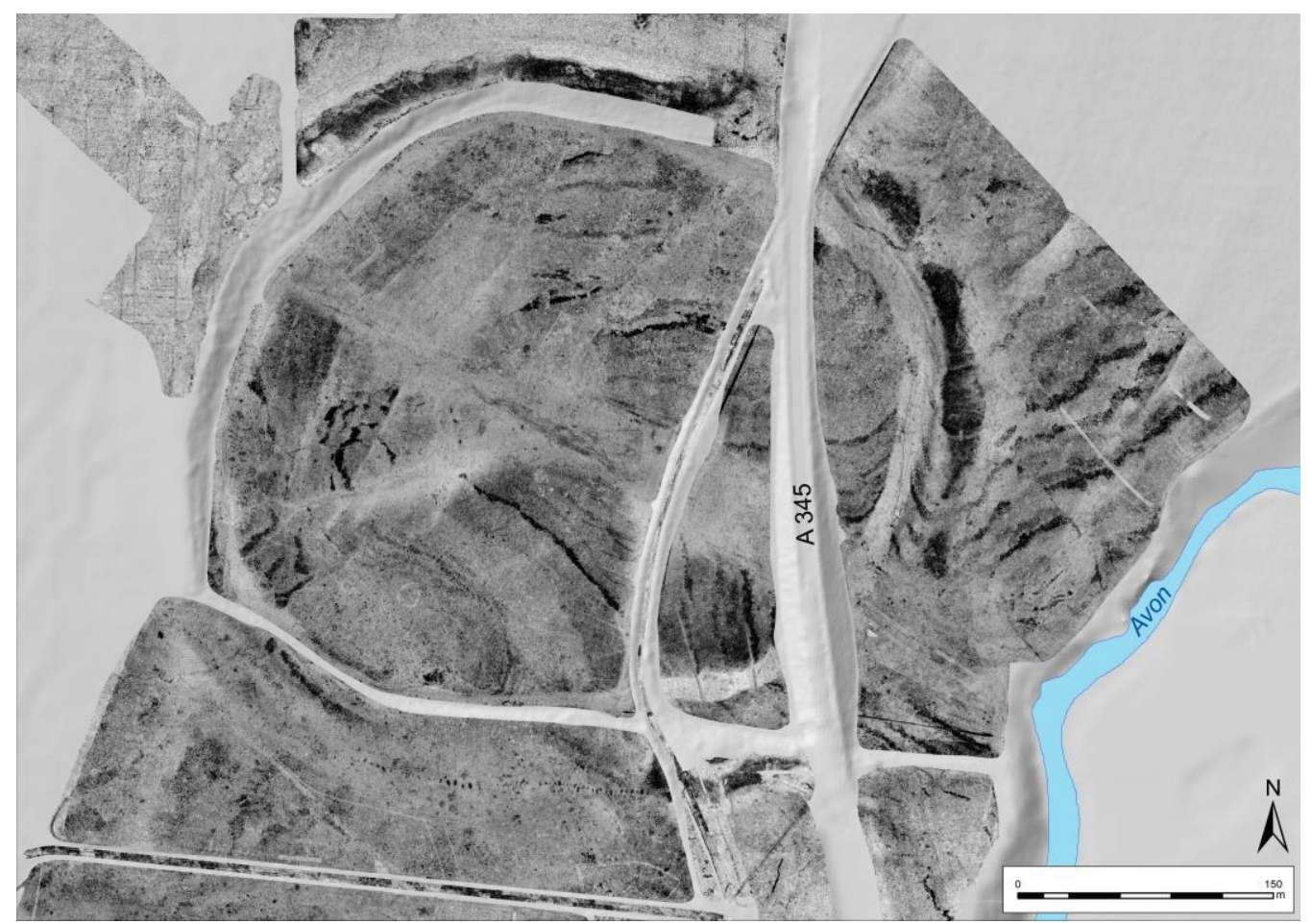

Figure 11: GPR data from Durrington Walls, visualisation of calculated depth slice $100-140 \mathrm{~cm}$ . (LBI ArchPro, Mario Wallner \& Klaus Löcker) 


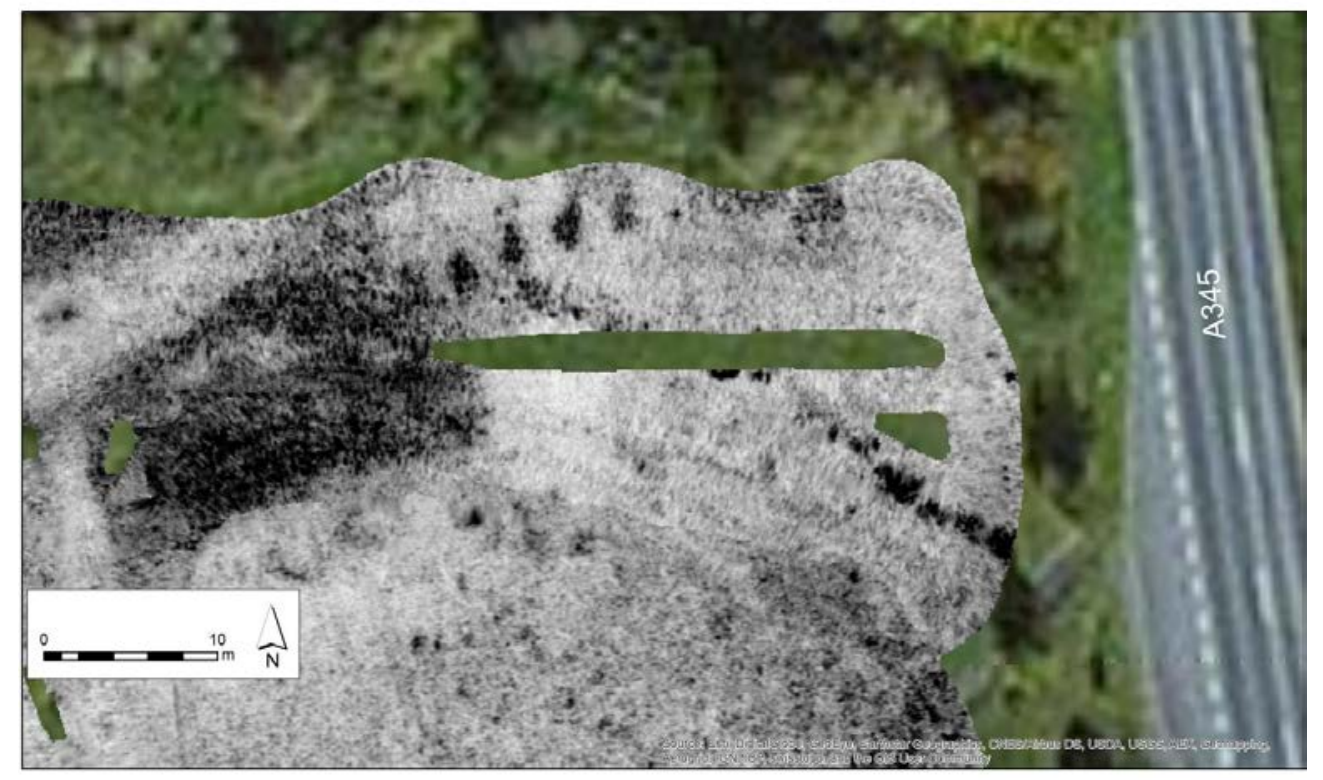

Figure 12: Features located west of the A345. (LBI ArchPro, Mario Wallner \& Klaus Löcker) 


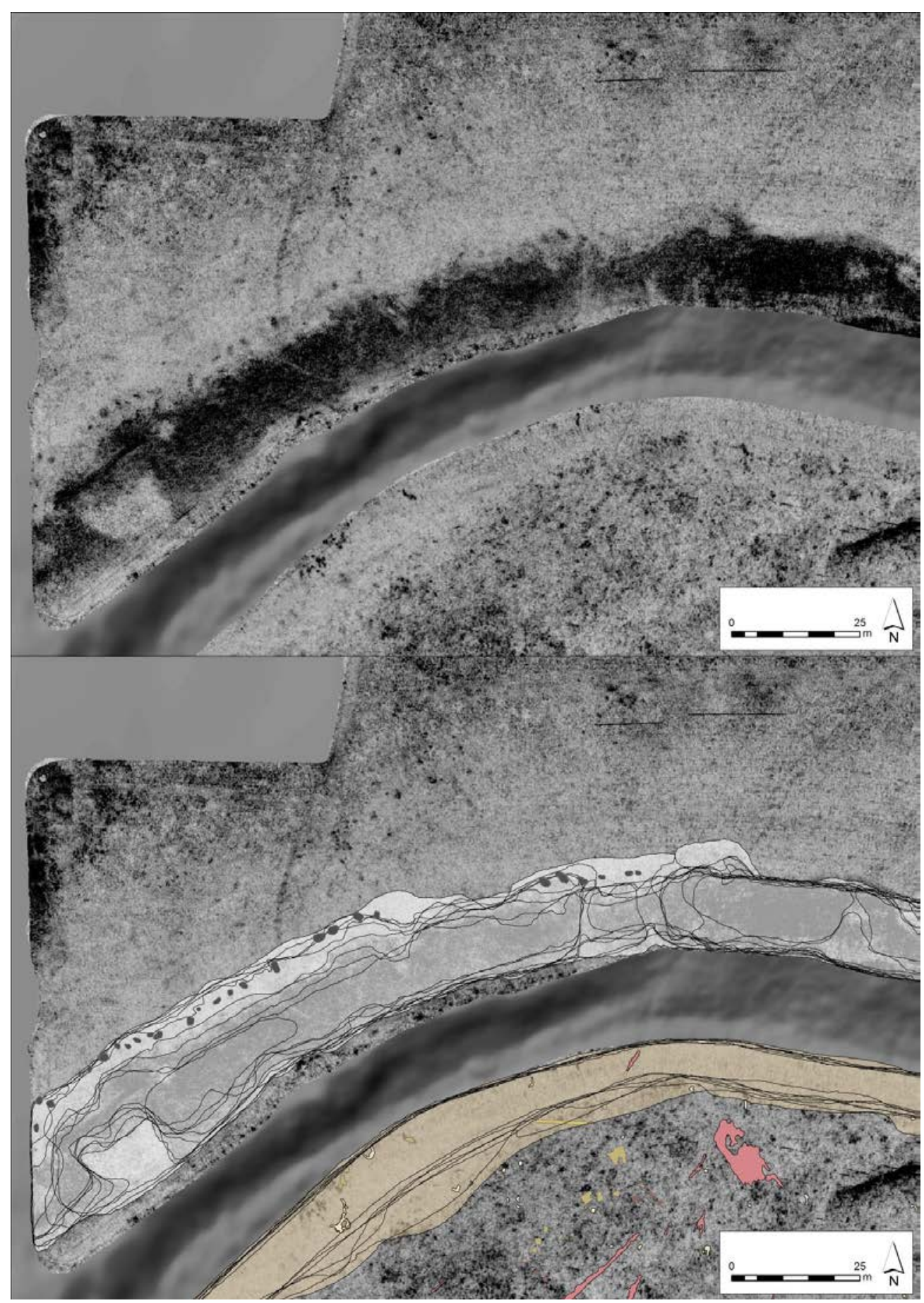

Figure 13: Features located in the north western sector of the A345. (LBI ArchPro, Mario Wallner \& Klaus Löcker) 
As a result of the SHLP surveys undertaken at Durrington Walls, a total of c.130 pre-henge bank features have so far been identified, apparently arrayed in two separate curving lines, both c. $50 \mathrm{~m}$ from the outer edge of the henge ditch (Fig. 14). Given their regular spacing it is estimated that the gap resulting from modern building and inaccessible land in the western sector of the monument might contain a further 80 features connecting those known from survey. Unfortunately, the disturbance caused by construction of the A345 is such that no direct link can be demonstrated with the features recorded by the SRP within the henge entrance, especially the large post-pits to the north of House 851 (Parker Pearson 2012; pers. comm.). Several large pits identified on the line of the northern bank after bulldozing of the $A 345$ route prior to road construction in 1967 (Wainwright 1971, 15), are also similar in size, spacing and alignment to the features recorded by the SHLP. However, if these are related to the SHLP discoveries it is curious that there is no evidence for further features continuing the alignment to meet those found further west of the features shown in figure 13 or to the east of the $A 345$ and north of the excavations undertaken by the SRP.

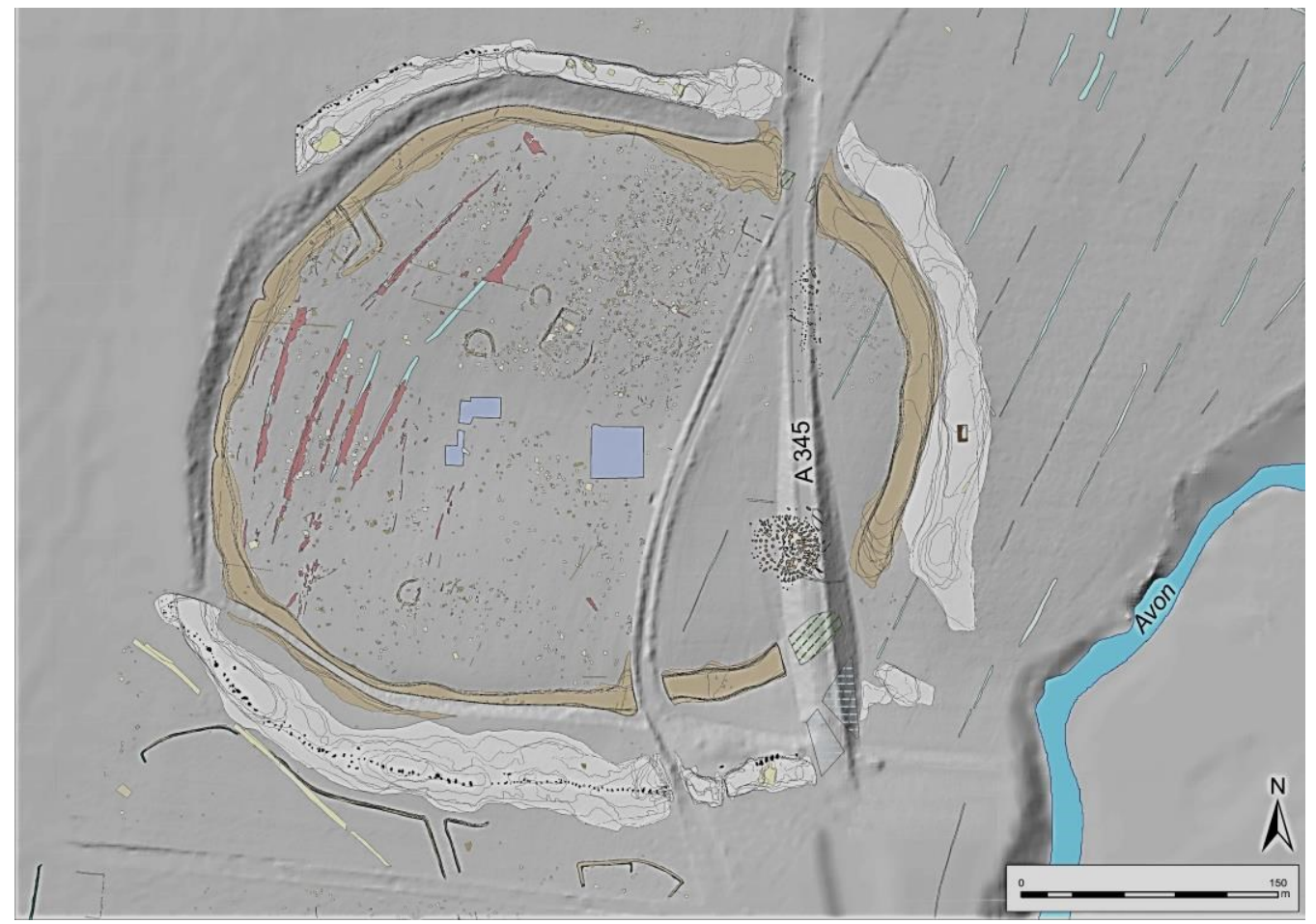

Figure 14: Interpretative map of Durrington Walls with anomalies highlighted. (LBI ArchPro, Mario Wallner \& Klaus Löcker)

The SHLP surveys have also produced some intriguing and potentially highly significant new data relating to the henge earthworks. There appears, for example, to be no certain evidence for a north-west entrance. The air photograph used by Crawford (1929, 54-6, pl.III) might indicate such an entrance, but this also seems to show a gap in the ditch on the east side of the enclosure which certainly does not exist. The land surface in the area of the supposed entrance is steep and very uneven, apparently 
heavily-disturbed, suggesting relatively recent modification of the scarp slope possibly to create an entrance ramp into the field within the enclosure area, which might account for the 'gap' observed by Crawford. The geophysical survey data (GPR and FDEM) are ambiguous, but there is certainly a suggestion that the ditch is continuous (see fig. 15). It is possible, therefore, that the Durrington Walls henge enclosure only had a single south-east entrance.

Equally significant is a consideration of the relationship between the bank and ditch. It has long been recognised that the enclosure bank is not concentric with the associated ditch, which curves further out to the south, and that it also varies in scale, being narrower on the north side and significantly wider and more massive on the south (Wainwright \& Longworth 1971). This is supported by the SHLP data, although the constructional form of the bank may need further investigation as the dispersal of the bank material indicated by the GPR and FDEM data suggests that the bank ran up to the edge of the chalk scarp, which until now has usually been seen as an historic agricultural feature. 


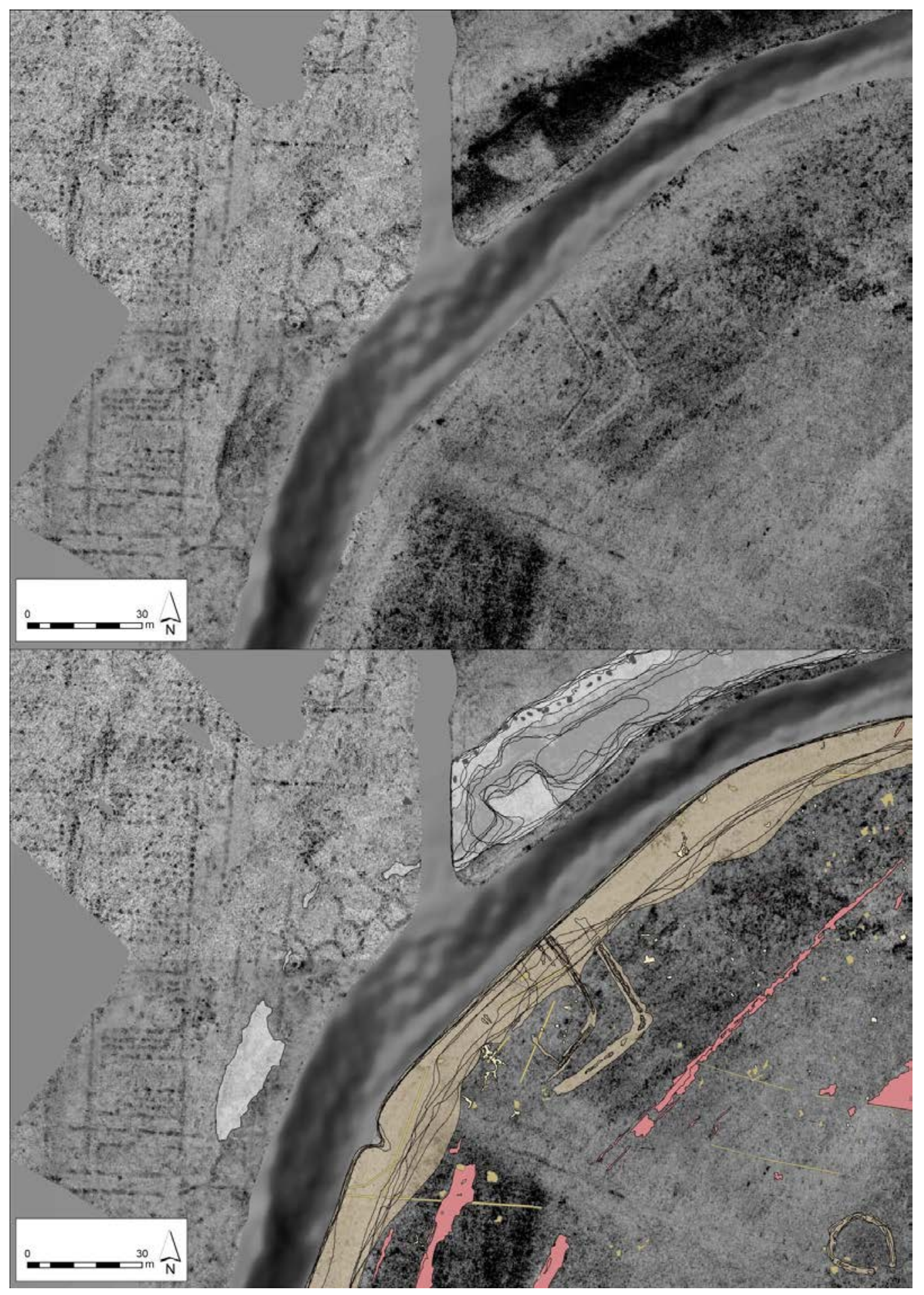


Figure 15: GPR data from the north-western quarter of Durrington Walls, showing possible continuous henge ditch line. (LBI ArchPro, Mario Wallner \& Klaus Löcker)

The potential for the scarp not to post-date the enclosure but to be contemporary with - or rather predate - the bank and ditch is further strengthened when the position of the ditch in relation to the scarp is considered. Profiles collected by the team across the high-resolution terrain model, shown in figure 7 , suggest that the ditch lies at the base of the scarp slope, which almost certainly already existed at the time the ditch was dug. It is thus most likely that the scarp was created by terracing into the valley slope prior to cutting the ditch, probably to delineate the curving form of the intended monument and to facilitate the great scale of ditch excavations required. The alternative explanation, that the henge ditch was dug before the scarp was created, seems very unlikely: this would have required excavation of the ditch from a significantly higher position than appears sensible, or even feasible, on a steep dry valley slope. Although the scarp may have been eroded back further by agricultural activity during historic periods, there is now no reason to imagine this process created the scarp originally.

The results of the surveys at Durrington Walls and the location of a coherent series of features, underlying the bank on the south, west and north sides of the monument raise a number of questions concerning the presumed sequence and structure of the monument. In the absence of absolute dating, this interpretation is based only on a relative sequence of architectural components and their spatial relationships, but the survey data clearly suggest that the structural development of the enclosure at Durrington Walls was more complex than previously appreciated, possibly comprising three distinct construction phases. This sequence can be summarised as follows:

1) Demarcation of a huge arena-like space by cutting back the head of the dry valley, perhaps making use of a pre-existing break of slope, to create a curving scarp up to $7 \mathrm{~m}$ high around the western half of the valley, framing the natural amphitheatre within.

2) Elaboration of the scarp-defined arena through construction of a line of at least 200 features, probably containing - or intended to contain - uprights, in a curving, slightly meandering, line around the scarp on its south, west and north sides. This line of features has been traced from the modern A345, where it cuts the line of the bank on the south side of Durrington Walls, extending westwards and probably continuing under the modern houses and gardens on the west side of the scarp, to emerge to the north, apparently ending within the north-west quadrant of the later enclosure bank. This forms what appears to be a C-shaped monument with an open side to the east. It is quite possible that this may represent an unfinished structure that was superseded by the construction of the henge enclosure. Alternatively, it is possible that the geophysical survey techniques applied have not located similar features on the north and east sides of the site, and that they once formed a more continuous circuit. It is likely that excavation will be the only way to definitively solve this conundrum.

3) Construction of a new, more conventional embanked henge enclosure. This involved digging the internal ditch at the base of the scarp, and erection of the huge outer bank that followed the outer edge of the scarp on its west and north sides but also extended around to the east to fully enclose the dry valley. The monumental south-east entrance was created at this time. This construction process would have involved destruction and/or assimilation of the row of uprights of the preceding phases.

This sequence may help to account for the uneven, non-concentric arrangement of the Durrington Walls henge architecture. This was probably due to the need of the builders to take account of pre-existing monumental structures and terrain features, especially the scarp, when digging the ditch, notably along its straighter southern section. In contrast, the henge bank was designed to be more conventionally circular in form, curving outwards and widening to the south, probably leaving a much wider berm on 
the south side in comparison with the rest of the circuit. It is especially notable that the line of features located by the SHLP surveys closely parallels the course of the scarp, set back consistently some $50 \mathrm{~m}$ from its edge, and not the bank. As a consequence of this, the row of features on the south side was buried by bank construction where this curved to the south, whereas on the north side the row of features runs at the back of the bank or under the bank talus. It may be no coincidence that the features in this area are less distinct, and increasingly less so eastward, perhaps because they were less deeply buried by bank material and hence more vulnerable to plough truncation. These observations strongly reinforce the view that the layout of the pre-henge row of features respected - and indeed monumentally elaborated - a pre-existing scarp feature around the valley, and that the henge bank was built without any desire to follow or reproduce the line of features in earthwork form. The newly discovered features, whatever they represent, are thus most likely to represent a distinctive monument with its own meaning and significance that was never intended to prefigure henge construction or emulate henge enclosure design.

The wider significance of the features discovered in the course of the SHLP surveys very much depends on their dating and their chronological and spatial relationships with the late Neolithic settlement. In particular, if they pre-date the settlement, the presence of a significant earlier monument at Durrington Walls throws open current interpretations of the process of sacralisation and monumentalisation not only locally but across the whole Stonehenge landscape. An early suggestion that some of the features contained stones may have been more provocative as this would directly challenge the premise at the heart of the Stonehenge Riverside Project, and the interpretative framework that stems from it. Whilst the existence of stones at Durrington Walls is currently conjectural given the results of a recent joint excavation by the SHLP and the SRP in 2016 (Current Archaeology 320), the presence of known standing stones in the immediate area, including the Cuckoo Stone (Thomas et al. 2009, 42) and sarsens at Woodhenge (Pollard \& Robinson 2007), suggest that stone structures on or near the site should not be discounted. If substantial monumental structures, whether stone or timber, existed at the time the settlement was occupied, it may be that the settlement was less extensive than has been suggested and/or had a particular social and religious purpose in relation to the monument it was adjacent to.

If the new features post-date the settlement, this has less impact on the SRP interpretative framework, though this would still demand a major reconsideration of the sequences, temporalities and purposes of construction tasks and related activities at Durrington Walls, with wider implications for our understanding of social effort and organisation in the mid-3rd millennium BC. In particular, the very narrow timeframe suggested by Bayesian modelling of the Durrington Walls radiocarbon dates (Parker Pearson 2012, 110) would in this scenario point to settlement (possibly on an extensive scale with dense occupation), construction of several small enclosures and timber buildings, settlement abandonment, construction of the new timber or stone monument (a major undertaking in its own right, whether completed or not), abandonment of this monument, and finally a massive henge enclosure and timber circle construction project, all within a period of less than 75 years, even within a generation. Whilst certainly not impossible, this would suggest a period of very rapid and far-reaching social and perhaps religious change, and does not account for the creation of the scarp or its apparent relationship with the newly discovered stone/timber monument.

Although this report presents only a very small sample of the results of the Stonehenge Hidden Landscapes Project, relating to just one period, they clearly offer significant new insights into the social structuring and changing character of the Stonehenge landscape. At Durrington Walls, for example, the combined results of multiple remote sensing surveys have added an entire new phase of construction 
and use to a monument that has been studied intensively for many years. This does not dismiss the need for 'ground-truthing', as the 2016 excavation demonstrated, to refine the results of survey, and recover the evidence needed for chronological, environmental and social interpretation, though this is most productive when undertaken in combination with careful assessment of geophysical data. Overall, it is clear that the results of the SHLP investigations at Durrington Walls exemplify the validity of the core premises of the project team that multiple survey methods should always be utilised in order to extract the most information from such work, and that the greatest benefits of carrying out such research accrue at a landscape scale of enquiry (Gaffney C. et al. 2013; Gaffney V. et al. 2013, Löcker et al. 2013; Neubauer et al. 2013). 


\section{Acknowledgments}

The Ludwig Boltzmann Institute for Archaeological Prospection and Virtual Archaeology (hppt://archpro.lbg.ac.at) is based on an international cooperation of the Ludwig Boltzmann Gesellschaft (A), Amt der Niederösterreichischen Landesregierung (A), University of Vienna (A), Vienna University of Technology (A), ZAMG - Central Institute for Meteorology and Geodynamics (A), Airborne Technologies (A), 7reasons (A), ÖAW Austrian Academy of Sciences (A), ÖAl - Austrian Archaeological Institute (A), RGZM Mainz - Römisch-Germanisches Zentralmuseum Mainz (D), University of Birmingham (GB), Arkeologerna of Statens Historiska Museer (S), NIKU - Norwegian Institute for Cultural Heritage (N), and Vestfold fylkeskommune - Kulturarv (N).

Fieldwork at Durrington Walls was carried out by Klaus Löcker, Eamonn Baldwin, Mario Wallner, Sebastian Flöry, Tanja Trausmuth, Jakob Kainz, Viktor Jansa, Erich Nau, Roland Filzwieser, Manuel Gabler, Vlad Sandici, Geert Verhoeven, Julia Wilding, Petra Schneidhofer, Phillipe deSmedt, Richard Bates, Christopher Gaffney, Vince Gaffney, Alex Corkum and Paul Garwood.

Data processing, visualisation and mapping was conducted by Alois Hinterleitner, Mario Wallner, Klaus Löcker, Wolfgang Neubauer, Jakob Kainz, Agatha Lugmayer, Georg Zotti, Michael Doneus, Lisa Aldrian, Eamonn Baldwin, Henry Chapman, Chris Gaffney, Vince Gaffney, Alex Corkum, Alexandra Vonkilch, Tanja Trausmuth, Marie Kröhl, Doris Schlögelhofer, Vlad Sandici, Petra Schneidhofer, and Immo Trinks. We would like to thank; the landowners: Richard Bawden, Stanley Rawlins, the MoD (in particular Richard Osgood) and the National Trust (in particular Nicola Snashall), as well as tenant farmers Robert Turner, Hugh Morrison, Christopher King and Philip Sawkill. We are indebted to the monument custodians of Historic England: in particular Phil McMahon and Amanda Chadburn. Julian Richards provided invaluable discussion during the fieldwork. The Wiltshire and Swindon Historic Environment Record were also helpful in supplying data. The project has benefitted through support from MALÅ Geoscience (http:// www.malags.com/home), Foerster Group

(http://www.foerstergroup.com/HomeDM.22.0.html), Pico Envirotec (http://www.picoenvirotec.com/environment/) and Riegl LMS (www.riegl.com/). We would like to thank Professor Larry Conyers for facilitating the prompt publication of this article.

\section{References}

Allen, M., Chan, B., Cleal, R., French, C., Marshall, P., Pollard, J., Pullen, R., Richards, C., Ruggles, C., Robinson, M., Rylatt, J., Thomas, J., Welham, K. and Parker Pearson. M., 2016. Stonehenge's Avenue and 'Bluestonehenge', Antiquity 90, 991-1008.

Barker, C., Schlanger, N., and Tournoux, M.-N., 2015: Report on the Joint World Heritage Centre/ICOMOS Advisory Mission to Stonehenge, Avebury and Associated Sites, 27-30 October 2015. UNESCO Report.

Bowden, M.C.B., Barber, M., Field, D. \& Soutar, S., 2016. The Stonehenge Landscape: analysing the Stonehenge World Heritage Site. Swindon: English Heritage.

Cleal, R.M.J., Walker, K.E. and Montague, R. 1995. Stonehenge in its Landscape: twentieth-century excavations. London: English Heritage.

Crawford, O.G.S., 1929. Durrington Walls, Antiquity 3, 49-59.

Darvill, T., 2005. Stonehenge World Heritage Site: an archaeological research framework. London: English Heritage.

Darvill, T., Marshall, P., Parker Pearson, M., and Wainwright, G., 2012. Stonehenge remodelled, Antiquity 86, 1021-40. 
Darvill, T., Lüth, F,. Rassmann, K., Fischer, A. and Winkelmann, K., 2013. Stonehenge, Wiltshire, UK: high resolution geophysical surveys in the surrounding landscape, 2011, European Journal of Archaeology 16 (1), 63-93.

David, A. and Payne, A., 1997. Geophysical surveys within the Stonehenge landscape: a review of past endeavour and future potential. In Renfrew, C. and Cunliffe, B. (eds.), Science and Stonehenge (Proceedings of the British Academy 92), 73-113. Oxford: Oxford University Press.

De Smedt, P., van Meirvenne, M., Saey, T., Baldwin, E., Gaffney, C., \& Gaffney, V., 2014: Unveiling the prehistoric landscape at Stonehenge through multi-receiver EMI, Journal of Archaeological Science 50, 16-23.

Field, D., Linford, N., Anderson-Whymark, H., Barber, M., Bowden, M., Linford, P. \& Topping, P., 2014. Analytical surveys of Stonehenge and its environs, 2009-2013: Part 1. Landscape and earthworks. Proceedings of the Prehistoric Society 80, 1-32.

French, C., Scaife, R., Allen, M. J., Parker Pearson, M., Pollard, J., Richards, C., Thomas, J., and Welham, K., 2012. Durrington Walls to West Amesbury by way of Stonehenge: a major transformation of the Holocene landscape, Antiquaries Journal 92, 1-36.

Gaffney, C., Gaffney, V., Neubauer, W., Baldwin, E., Löcker, K., 2013. An integrated geophysical approach to Stonehenge. In Neubauer, W., Trinks, I., Salisbury, RB., Einwögerer, C. (eds), Archaeological Prospection. Proceedings of the 10th International Conference on Archaeological Prospection, Vienna 2013, 230. Wien: Verlag der Österreichischen Akademie der Wissenschaften.

Gaffney V., Gaffney C., Garwood P., Neubauer W., Chapman H., Löcker K., Baldwin E., 2013. Stonehenge Hidden Landscapes Project: geophysical investigation and landscape mapping of the Stonehenge World Heritage Site. In Neubauer, W., Trinks, I., Salisbury, R. B., Einwögerer, C. (eds.), Archaeological Prospection. Proceedings of the 10th International Conference on Archaeological Prospection, Vienna 2013, 19-23. Wien: Verlag der Österreichischen Akademie der Wissenschaften

Gaffney, C., Gaffney, V., Neubauer, W., Baldwin, E., Chapman, H., Garwood, P., Moulden, H., Sparrow, T., Bates, R., Löcker, K., Hinterleitner, A., Trinks, I., Nau, E., Zitz, T., Floery, S., Verhoeven, G., Doneus, M., 2012. The Stonehenge Hidden Landscapes Project, Archaeological Prospection 19 (2), 147-55.

Garwood, P. 2007. Before the hills in order stood: chronology, time and history. In J. Last (ed.), Beyond the Grave: new perspectives on barrows, 30-52. Oxford: Oxbow Books

Garwood, P., 2012: The present dead: the making of past and future landscapes in the British Chalcolithic. In Allen M.J., Gardiner J. and Sheridan, A., (eds.), Is there a British Chalcolithic? People, place and polity in the later $3^{\text {rd }}$ millennium, 297-315. Oxford: Prehistoric Society Monograph Series 4

Hilts, C., 2016: Rethinking Durrington Walls: a long-lost monument revealed beneath a famous henge, Current Archaeology 320, 38-45

Linford, N., Linford, P. and Payne, A., 2012. Stonehenge Monument Field and Barrows, Wiltshire - Report on Geophysical Surveys, September 2010, April and July 2011. English Heritage Research Department Report Series no. 34-2012. London: English Heritage 
Löcker, K., Baldwin, E., Neubauer, W., Gaffney, V., Gaffney, C., Hinterleitner, A., Garwood, P., Trinks, I. and Wallner, M., 2013. The Stonehenge Hidden Landscape Project - data acquisition, processing, interpretation. In Neubauer, W., Trinks, I., Salisbury, R. B., Einwögerer, C. (eds.), Archaeological Prospection. Proceedings of the 10th International Conference on Archaeological Prospection, Vienna 2013, 107-9. Wien: Verlag der Österreichischen Akademie der Wissenschaften.

Neubauer, W., Doneus, M., Trinks, I., 2012. Advancing the documentation of buried archaeological landscapes, International Archives of the Photogrammetry, Remote Sensing and Spatial Information Sciences XXXIX-B5, 547-52.

Parker Pearson, M., 2007. The Stonehenge Riverside Project - excavations at the east entrance of Durrington Walls. In Larsson, L. and Parker Pearson, M. (eds), From Stonehenge to the Baltic: living with cultural diversity in the third millennium BC. Oxford: British Archaeological Reports, International Series $1692,125-44$.

Parker Pearson, M., 2012. Stonehenge: exploring the greatest Stone Age mystery. London: Simon \& Schuster.

Parker Pearson, M. and Ramilisonina, 1998. Stonehenge for the ancestors, the stones pass on the message, Antiquity 72, 308-26.

Parker Pearson, M., Richards, C., Allen, M., Payne, A. and Welham, K. 2004: The Stonehenge Riverside project: research design and initial results, Journal of Nordic Archaeological Science 14, 45-60.

Parker Pearson, M., Cleal, R., Marshall, P., Needham, S., Pollard J., Richards, C., Ruggles, C., Sheridan, A., Thomas, J., Tilley, C., Welham, K., Chamberlain, A., Chenery, C., Evans J., Knüsel, C., Linford, N., Martin, L., Montgomery, J., Payne, A. and Richards. M., 2007. The age of Stonehenge, Antiquity 81, 617-39.

Payne, A., 2003. Durrington Walls Henge, Wiltshire. Report on Geophysical Surveys, January 1996 and April 2003. Centre for Archaeology Report Series 107/2003. Portsmouth: English Heritage.

Payne, A., 2004. Durrington Walls Henge, Wiltshire: Report on Geophysical Survey, April 2004. Centre for Archaeology Reports Series 71/2004. Portsmouth: English Heritage.

Pollard, J. \& Robinson, D., 2007. A return to Woodhenge: the results and implications of the 2006 excavations. In Larsson, L. and Parker Pearson, M. (eds), From Stonehenge to the Baltic: living with cultural diversity in the third millennium BC. Oxford: British Archaeological Reports, International Series 1692, 159-68.

Thomas, J., 2007. The internal features at Durrington Walls: investigations in the Southern Circle and western enclosures 2005-6. In Larsson, L. and Parker Pearson, M. (eds), From Stonehenge to the Baltic: living with cultural diversity in the third millennium BC. Oxford: British Archaeological Reports, International Series 1692, 145-57.

Thomas, J., Marshall, P., Parker Pearson, M., Pollard, J., Richards, C., Tilley, C. and Welham, K., 2009. The date of the Greater Stonehenge Cursus, Antiquity 83, 40-53. 
Trinks, I., Johansson, B., Gustafsson, J., Emilsson, J., Friborg, J., Gustafsson, C., Nissen, J., 2010. Efficient, Large-scale Archaeological Prospection using a True Threedimensional Ground-penetrating Radar Array System. Archaeological Prospection 17(3), 175-86.

Trinks, I., Neubauer, W., and Doneus, M., 2012. Prospecting archaeological landscapes. In loannides, M., Fritsch, D., Leissner, J., Davies, R., Remondino, F. and Caffo, R (eds.), Progress in Cultural Heritage Preservation, 21-9. Proceedings of the 4th International Conference, Euro-Mediterranean 2012, Limassol, Cyprus, 2012. Berlin Heidelberg: Springer-Verlag.

Trinks, I., Neubauer, W., Doneus, M., Hinterleitner, A., Doneus, N., Verhoeven, G., Löcker, K., Kucera, M., Nau, E., Wallner, M., Seren, S., 2015. Interdisciplinary archaeological prospection at unprecented scale and resolution. The first five years of the LBI ArchPro Research Initiative 2010-2015. In

RzeszotarskaNowakiewicz, A (ed.), Archaeological Prospection. Proceedings of the 11th International Conference on Archaeological Prospection, Warsaw 2015 (Archaeologia Polona 53), 144-47. Warsaw: The Institute of Archaeology and Ethnology, Polish Academy of Sciences.

Wainwright, G.J. and Longworth, I.H., 1971. Durrington Walls: excavations 1966-1968. London: Society of Antiquaries Research Report 29.

Woodward, A. and Woodward, P.J., 1996. The topography of some barrow cemeteries in Bronze Age Wessex. Proceedings of the Prehistoric Society 57, 103-57. 